\title{
Populasi Bakteri Normal dan Bakteri Kitinolitik Pada Saluran Pencernaan Lobster Pasir (Panulirus homarus L.) yang diberi Kitosan
}

\author{
Baiq Nihayatun Nufus ${ }^{1}$, Galuh Tresnani ${ }^{1}$ dan Faturrahman ${ }^{1}$ \\ ${ }^{1}$ Program Studi Biologi Fakultas Matematika dan Ilmu Pengetahuan Alam Universitas Mataram \\ Jl. Majapahit No. 62 Mataram 83125, Tlp/Fax. 0370 646506, \\ e-mail: nihayabq@gmail.com
}

\begin{abstract}
ABSTRAK
Pertumbuhan lobster pasir (Panulirus homarus) sangat bergantung pada bakteri-bakteri yang terdapat pada saluran pencernaan. Salah satu upaya untuk meningkatkannya adalah dengan penambahan kitosan yang akan berpengaruh terhadap bakteri-bakteri kitinolitik saluran pencernaan lobster. Tujuan penelitian ini untuk mengetahui perbandingan jumlah bakteri kitinolitik dan bakteri normal pada saluran pencernaan lobster pasir (Panulirus homarus). Penelitian dilakukan selama 3 bulan di Balai Perikanan Budidaya Laut Lombok, Sekotong. Penelitian ini menggunakan rancangan acak lengkap (RAL) dengan 4 perlakuan dan 3 ulangan dengan variasi berat kitosan per-kg pakan $(0 \mathrm{~g}, 1 \mathrm{~g}, 2 \mathrm{~g}$ dan $4 \mathrm{~g})$. Sampel yang diambil dari saluran pencernaan lobster yaitu bagian usus dan lambung. Seri pengenceran $10^{-6} \mathrm{cfu} / \mathrm{ml}, 10^{-7} \mathrm{cfu} / \mathrm{ml} \mathrm{dan} 10^{-8} \mathrm{cfu} / \mathrm{ml}$ diisolasi pada media Plate Count Agar (PCA) dan dimurnikan pada media agar kitin. Perhitungan total bakteri menggunakan analisis Total Plate Count (TPC). Hasil penelitian variasi berat kitosan diperoleh angka lempeng total bakteri pada kontrol, P1, P2 dan P3 secara berturut-turut pada media PCA adalah 49,5x10 ${ }^{9}$ $\mathrm{cfu} / \mathrm{ml}, 52,1 \times 10^{9} \mathrm{cfu} / \mathrm{ml}, 25,1 \times 10^{9} \mathrm{cfu} / \mathrm{ml}$ dan $15,8 \times 10^{9} \mathrm{cfu} / \mathrm{ml}$ dan pada media agar kitin adalah $5 \times 10^{7}$ $\mathrm{cfu} / \mathrm{ml}, 272 \times 10^{7} \mathrm{cfu} / \mathrm{ml}, 241 \times 10^{7} \mathrm{cfu} / \mathrm{ml}$ dan $55 \times 10^{7} \mathrm{cfu} / \mathrm{ml}$. Jumlah populasi bakteri tertinggi pada P1 sebesar $52,1 \times 10^{9} \mathrm{cfu} / \mathrm{ml}$ pada media PCA dan P1 pada media kitin agar sebesar $272 \times 10^{7} \mathrm{cfu} / \mathrm{ml}$. Berdasarkan hasil analysis of variance (ANOVA 5\%) menunjukkan perlakuan variasi berat kitosan per-kg pakan tidak berpengaruh nyata.
\end{abstract}

Kata kunci: lobster pasir, bakteri normal, bakteri kitinolitik, saluran pencernaan, kitosan, metode TPC.

\begin{abstract}
The grow of sand lobster (Panulirus homarus L.) is extremely depend on a lot of bacteria which is found at digestive system. On of the effort to increase it for chitosan addition that influence to chitinolytic bacteria of sand lobster (Panulirus homarus L.) at digestive system. The research aimed to find out amount of comparation between chitinolytic bacteria and normal bacteria of sand lobster (Panulirus homarus L.) at digestive system which is donefor for three months at Mariculture Hall Lombok, Sekotong. This research use completely randomized design with 4 treatment and 3 test of variation weight of chitosan each $\mathrm{kg}$ woof $(0 \mathrm{~g}$, $1 \mathrm{~g}, 2 \mathrm{~g}$ dan $4 \mathrm{~g}$ ). The sampleis taken through its colon and stomach. Melting series $10^{-6} \mathrm{cfu} / \mathrm{ml}, 10^{-7} \mathrm{cfu} / \mathrm{ml}$ dan $10^{-8} \mathrm{cfu} / \mathrm{ml}$ are isolated on Plate Count Agar (PCA) and be purified on Chitin Agar Media. The total calculation of bacteria that using Total Plate Count (TPC). The result of chitosan weight variationhas found a total plate count of bacteria on control, P1, P2 and P3 continuously at PCA media are $49,5 \times 10^{9} \mathrm{cfu} / \mathrm{ml}$, $52,1 \times 10^{9} \mathrm{cfu} / \mathrm{ml}, 25,1 \times 10^{9} \mathrm{cfu} / \mathrm{ml}$ dan $15,8 \times 10^{9} \mathrm{cfu} / \mathrm{ml}$ and Chitin Agar Media are $5 \times 10^{7} \mathrm{cfu} / \mathrm{ml}, 272 \times 10^{7}$ $\mathrm{cfu} / \mathrm{ml}, 241 \times 10^{7} \mathrm{cfu} / \mathrm{ml}$ dan $55 \times 10^{7} \mathrm{cfu} / \mathrm{ml}$. the highest is on P1 is about $52,1 \times 10^{9} \mathrm{cfu} / \mathrm{ml}$ and P1 for Chitin Agar Media is about $272 \times 10^{7} \mathrm{cfu} / \mathrm{ml}$. Based on the results of analysis of variance (ANOVA $5 \%$ ) show chitosan weight variation treatment each $\mathrm{kg}$ woof did not significantly affect.
\end{abstract}

Keywords: sand lobster, normal bacteria, bacteria chitinolytic, gastrointestinal tract, chitosan, TPC method. 


\section{Pendahuluan}

Bakteri normal adalah mikroorganisme yang menempati suatu daerah tanpa menimbulkan penyakit pada inang yang ditempati. Tempat paling umum dijumpai bakteri normal adalah tempat yang terpapar dengan dunia luar yaitu kulit, mata, mulut, saluran pernafasan atas, saluran pencernaan dan saluran urogenital (Trampuz et al, 2004).

Bakteri normal berperan penting dalam mensintesis vitamin, mensekresi enzim, dan membantu pencernaan nutrien. Bakteri normal dapat menekan pertumbuhan bakteri patogen sehingga dapat melindungi inang dari serangan penyakit serta merangsang fungsi kekebalan tubuh. Keseimbangan bakteri normal merupakan salah satu faktor yang sangat menentukan status kesehatan pada inang (Aslamyah et al., 2009).

Kesehatan inang juga berpengaruh terhadap pemberian pakan karena mampu meningkatkan bakteri normal pada saluran pencernaan. Selain itu pakan sangat penting untuk menunjang kelangsungan hidup inang.

Kitosan menjadi prebiotik alami yang diberikan bersamaan dengan pakan kombinasi pada lobster hijau pasir (Panulirus homarus). Kitosan memiliki gugus aktif yang akan berikatan dengan mikroba sehingga kitosan mampu menghambat pertumbuhan mikroba. Saat ini, kitosan telah diproduksi secara industri di negara-negara maju terutama Jepang dan Amerika Serikat dan mengalami peningkatan yang cukup tajam. Produksi kitosan ini, dapat mengurangi jumlah limbah cangkang udang atau cangkang crustacea lainnya yang jumlahnya sangat melimpah di alam dan dapat menjadikannya salah satu sumber daya alam alternatif untuk limbah cangkang (Mahatmanti \& Sumarni, 2003).
Penambahan kitosan pada pakan akan berpengaruh terhadap bakteribakteri kitinolitik saluran pencernaan lobster. Bakteri kitinolitik merupakan kelompok bakteri yang mampu menghasilkan enzim kitinase untuk menguraikan zat kitin (Budiani et al., 2004 dalam Fitri \& Yasmin, 2011). Rostinawati (2008) mengatakan bahwa enzim kitinase yang dihasilkan oleh bakteri kitinolitik berasal dari proses daur ulang kitin. Bakteri kitinolitik juga dapat mengubah kitin menjadi bahan organik sehingga dapat digunakan sebagai sumber nitrogen dan karbon.

Penambahan kitosan pada pakan diharapkan mampu meningkatkan jumlah bakteri kitinolitik untuk membantu bakteri normal pada saluran pencernaan lobster pasir (Panulirus homarus) menekan pertumbuhan bakteri patogen dan menunjang kelangsungan hidup lobster.

\section{Bahan dan Metode}

Penelitian ini bersifat eksperimental menggunakan rancangan acak lengkap (RAL) dengan 4 perlakuan variasi berat kitosan per-kg pakan (0 g, 1 g, 2 g dan 4 g) dan 3 ulangan sehingga terdapat 12 unit percobaan. Penentuan jumlah kitosan yang diberikan berdasarkan pada penelitian Niu et al., (2011). Penelitian ini juga bersifat deskriptif eksploratif, karena penelitian ini dilakukan untuk mengetahui jumlah koloni bakteri pada saluran cerna lobster pasir. Penelitian ini dilaksanakan selama 3 bulan yaitu dari bulan Juni - Agustus 2015 di Balai Perikanan Budidaya Laut (BPBL) Desa Gili Genting, Sekotong, Kabupaten Lombok Barat, Provinsi Nusa Tenggara Barat. 


\section{Persiapan Wadah}

Wadah penelitian yang digunakan adalah bak beton sebanyak 1 buah, berukuran 4,85 × 2,9 × 1,6 m. Bak beton diisi 12 keranjang berukuran $0,5 \times 0,5 \times 1$ $\mathrm{m}$ (keranjang hasil modifikasi waring hitam) dan dilengkapi dengan shelter menggunakan waring hitam berlipat untuk meminimalisir kanibalisme.

\section{Persiapan Hewan Uji}

Lobster yang digunakan adalah lobster pasir (Panulirus homarus L.) yang dikumpulkan dari hasil tangkapan nelayan di Pantai Teluk Awang, Lombok Tengah, Nusa Tenggara Barat (NTB). Lobster yang baru tiba diaklimatisasi dan digrading. Aklimatisasi dan grading bertujuan untuk mengadaptasikan hewan uji dengan lingkungan yang baru dalam wadah penelitian dan pengelompokan hewan uji berdasarkan kisaran ukuran berat. Lobster diaklimatisasi selama 10 hari sebelum digunakan untuk penelitian. Selama proses ini, lobster diberi pakan yang tidak ditambahkan kitosan.

\section{Pembuatan Pakan}

Pakan terdiri atas $70 \%$ pakan alami udang putih dan $30 \%$ pakan alami tambahan, yang berupa Gracilaria sp. dan Diadema sp. (Trijoko, 2003). Penelitian ini menggunakan pakan alami yang menyesuaikan dengan makanan alami lobster di alam bebas berdasarkan data penelitian Mashaii et al. (2011). Pakan tersebut dibuat menjadi pellet dengan penambahan kitosan yang merupakan bahan komersil dan dipadukan dengan bahan-bahan pakan lainnya.

\section{Pemeliharaan Benih Lobster Pasir (Panulirus homarus L.)}

Pemeliharaan lobster pasir (Panulirus homarus L.) dilakukan selama 43 hari dan diberikan pakan berupa pellet sesuai perlakuan. Pakan diberikan 3 kali sehari sebesar $15 \%$ /hari dari biomassa lobster yaitu pukul 08.00 WITA sebanyak $5 \%$, pukul 14.00 WITA sebanyak $2 \%$ dan pukul 18.00 WITA sebanyak $8 \%$. Persentase pakan disesuaikan dengan pertambahan biomassa lobster setiap 14 hari sekali. Pengukuran kualitas air di bak pemeliharaan meliputi suhu, salinitas, $\mathrm{pH}$, oksigen terlarut $(D O)$, nitrat $\left(\mathrm{NO}_{3}\right)$, nitrit $\left(\mathrm{NO}_{2}\right)$, dan amonia $\left(\mathrm{NH}_{3}\right)$. Suhu air diambil setiap hari sebanyak 3 kali sehari yaitu pagi, siang dan sore, sedangkan derajat keasaman $(\mathrm{pH})$, oksigen terlarut (Dissolved Oxygen), salinitas, nitrat $\left(\mathrm{NO}_{3}\right)$, nitrit $\left(\mathrm{NO}_{2}\right)$, amonia $\left(\mathrm{NH}_{3}\right)$ diambil saat awal dan akhir penelitian serta dianalisis di laboratorim Balai Perikanan dan Budidaya Laut Lombok (BPBL).

\section{Pembuatan kitin}

Sampel yang digunakan untuk pembuatan kitin adalah limbah cangkang rajungan. Cangkang rajungan yang diperoleh dicuci hingga bersih dan dikeringkan dibawah sinar matahari selama satu hari. Cangkang kering kemudian digiling hingga menjadi serbuk halus. Proses pembuatan kitin selanjutnya meliputi tahap deproteinase dan tahap demineralisasi.

- Tahap deproteinasi: Sebanyak 50 gr serbuk kulit rajungan dimasukkan ke dalam erlenmeyer dan ditambahkan $\mathrm{NaOH} \quad 1 \quad \mathrm{~N}$ sebanyak $500 \quad \mathrm{ml}$. Campuran kemudian diaduk di atas magnetic stirer selama 2 jam pada suhu $80^{\circ} \mathrm{C}$. Endapan yang terbentuk 
dipisahkan dari filtrat. Endapan dicuci dengan akuades hingga $\mathrm{pH}$ netral dan selanjutnya dikeringkan dalam oven selama 24 jam pada suhu $60^{\circ} \mathrm{C}$ (Fitri \& Yasmin, 2011).

- Tahap demineralisasi: Sebanyak 24 gr kulit rajungan kering hasil deproteinasi dilarutkan dalam $\mathrm{HCl} 2 \mathrm{~N}$ sebanyak $240 \mathrm{ml}$. Campuran kemudian didiamkan pada suhu kamar. Endapan yang diperoleh dicuci dengan akuades hingga $\mathrm{pH}$ netral dan dikeringkan kembali dalam oven selama 24 jam pada suhu $60^{\circ} \mathrm{C}$, diperoleh kitin (Fitri \&Yasmin, 2011).

\section{Pembuatan Media Pertumbuhan Bakteri \\ - Media PCA}

Sebanyak 22,5 g serbuk media Plate Count Agar didispersikan dengan air laut steril hingga $1000 \mathrm{ml}$. Medium dididihkan di atas penangas air dan disterilkan di dalam autoklaf pada suhu $121^{\circ} \mathrm{C}$ selama 15 menit dengan tekanan di atas $1 \mathrm{~atm}$.

\section{- Media agar kitin}

Media agar kitin (gr/L) terbuat dari beberapa komposisi diantaranya 2 gr $\mathrm{NaNO}_{3}, 1$ gr yeast ekstrak, 0,5 gr $\mathrm{K}_{2} \mathrm{HPO}_{4}, \quad 0,2$ gr $\mathrm{MgSO}_{4}, 0,02$ gr $\mathrm{CaCl}_{2}$, 0,02 gr MnSO $4,0,02$ gr FeSO 4 , 20 gr Nutrien Agar dan 2 gr kitin dengan ditambahkan $1000 \mathrm{ml}$ air laut steril. Medium dididihkan di atas penangas air dan disterilkan di dalam autoklaf pada suhu $121^{\circ} \mathrm{C}$ selama 15 menit dengan tekanan di atas $1 \mathrm{~atm}$.

\section{Persentase Rendaman}

Rendemen kitin ditentukan berdasarkan persentasi berat kitosan yang dihasilkan terhadap berat bahan baku rajungan sebelum diproses (Zahiruddin, et al, 2008 dalam Agustina \& Kurniasih, 2013):

$$
\begin{aligned}
& \% \text { Rendaman } \\
& =\frac{\text { berat kitin yang di asilkan }}{\text { Berat awal }} \times 100 \%
\end{aligned}
$$

\section{Pengambilan Isi Saluran Pencernaan Lobster}

Isi saluran pencernaan lobster pasir dari tiap perlakuan dan ulangan diambil sebagai sumber inokulum melalui pembedaan. Bagian dari organ pencernaan digerus menggunakan mortar lalu ditimbang sebanyak $\pm 0,5 \mathrm{~g}$ (1-2 ekor lobster) menggunakan timbangan analitik. Saluran pencernaan lobster pasir yang telah halus diencerkan dengan 4,5 $\mathrm{mL}$ air laut steril, campuran ini dihomogenkan dengan vortex untuk mendapatkan larutan sampel dengan konsentrasi $10^{-2} \mathrm{cfu} / \mathrm{ml}$.

\section{Pengenceran Sampel}

Larutan stok dengan pengenceran $10^{-2} \mathrm{cfu} / \mathrm{ml}$ dicuplik sebanyak $1 \mathrm{~mL}$ dan dilarutkan kedalam air laut steril membentuk larutan seri pengenceran $10^{-3}$ $\mathrm{cfu} / \mathrm{ml}$. Larutan tersebut divortex hingga homogen. Prosedur yang sama dilakukan untuk membuat seri pengenceran sampai dengan $10^{-8} \mathrm{cfu} / \mathrm{ml}$.

\section{Isolasi Bakteri}

Larutan dengan seri pengenceran $10^{-}$ $6 \mathrm{cfu} / \mathrm{ml}, 10^{-7} \mathrm{cfu} / \mathrm{ml}$, dan $10^{-8} \mathrm{cfu} / \mathrm{ml}$ masing-masing diambil sebanyak $0,1 \mathrm{ml}$ kemudian isolasi pada media PCA dengan teknik sebar menggunakan spreader dan dilakukan secara duplo untuk setiap pengenceran. Biakan diinkubasi pada suhu $35{ }^{0} \mathrm{C}$ selama 48 jam. Setelah masa inkubasi, koloni bakteri yang tumbuh pada media PCA dihitung. Koloni bakteri yang tumbuh pada media PCA diisolasi ke media 
kitin agar dengan metode gores dan diinkubasi pada suhu $35^{\circ} \mathrm{C}$ selama 24 jam dan jumlah koloni bakteri yang tumbuh dihitung.

\section{Perhitungan Total Bakteri}

\section{Penghitungan Total Bakteri} menggunakan metode Total Plate Count (TPC) yang merupakan metode pendugaan jumlah mikroorganisme secara keseluruhan dari suatu bahan. Analisis TPC menggunakan media Plate Count Agar (PCA) dengan menanam 0,1 ml sampel dari pengenceran ke dalam cawan petri, kemudian diinkubasi selama 48 jam pada suhu $\quad 35^{\circ} \quad \mathrm{C} \quad$ (Zaki, 2012). Hasil penghitungan koloni berupa (cfu) per $\mathrm{ml} / \mathrm{g}$. Perhitungan koloni dilakukan pada seri pengenceran $\quad 10^{-6} \mathrm{cfu} / \mathrm{ml}, \quad 10^{-7}$ $\mathrm{cfu} / \mathrm{ml}$, dan $10^{-8} \mathrm{cfu} / \mathrm{ml}$. Koloni bakteri diletakkan pada cawan petri dalam kamar hitung, alat penghitung diatur pada posisi nol dan koloni bakteri mulai dihitung dengan menggunakan jarum penunjuk sambil melihat jumlah pada layar hitung. Perhitungan jumlah koloni dari 30-300 koloni menggunakan rumus sebagai berikut (Fardiaz, 1993 dalam Damongilala, 2009):

\section{Total Bakteri \\ $=$ Iumla koloni Bakteri $x \frac{1}{\text { Pengenceran }}$}

\section{Analisis Data}

Data hasil penelitian dianalisis dengan menggunakan Analisis Varian Satu Arah pada taraf signifikansi 5\% untuk mengetahui pengaruh. Data dianalisis dengan Microsoft Excel.

\section{Hasil dan Pembahasan}

\section{Ekstrak Kitin}

Ekstrak kitin diperoleh dari limbah cangkang rajungan kering dalam bentuk serbuk. Data hasil rendaman isolasi kitin dari cangkang rajungan diperoleh sebesar $14 \%$. Hasil kitin yang diperoleh sedikit, hal ini dipengaruhi tahapan isolasi kitin, pada penelitian ini urutan isolasi kitin dimulai dari deproteinasi-demineralisasi sedangkan pada penelitian Agustina \& Kurniasih (2013) urutan isolasi kitin dari demineralisasi-deproteinasi diperoleh \% rendemen kitin sebesar 36,76\%. Isolasi dengan urutan demineralisasideproteinasi menghasilkan rendemen lebih banyak dibandingkan dengan tahap isolasi deproteinasi-demineralisasi. Hal ini disebabkan karna mineral membentuk shield (pelindung) yang keras pada kulit udang, sehingga dengan menghilangkan mineral terlebih dahulu akan mempermudah proses penghilangan protein sehingga $\%$ rendemen kitin lebih besar.

\section{Total Bakteri Saluran Pencernaan Lobster}

TPC merupakan metode yang sering digunakan dalam analisa jumlah mikroorganisme. Jumlah mikroorgnisme dapat langsung dihitung setelah tumbuh dan berkembang biak dengan membentuk koloni-koloni. 
Tabel 1.Angka Lempeng Total Bakteri pada Saluran Pencernaan Lobster Pasir pada Media PCA

\begin{tabular}{cc}
\hline Percobaan & Media PCA $(\mathrm{cfu} / \mathrm{ml})$ \\
\hline Kontrol & $49,5 \times 10^{9} \mathrm{cfu} / \mathrm{ml}$ \\
P1 & $52,1 \times 10^{9} \mathrm{cfu} / \mathrm{ml}$ \\
P2 & $25,1 \times 10^{9} \mathrm{cfu} / \mathrm{ml}$ \\
P3 & $15,8 \times 10^{9} \mathrm{cfu} / \mathrm{ml}$ \\
\hline
\end{tabular}

Keterangan: $\mathrm{cfu} / \mathrm{ml}=$ colony forming unit/ $\mathrm{ml}$

Jumlah koloni yang tumbuh pada media PCA sangat beragam dengan jumlah dari masing-masing percobaan. Pada kontrol yang diberikan 0 gr kitosan / $\mathrm{kg}$ pakan memiliki angka lempeng total bakteri sebesar $49,5 \times 10^{9} \mathrm{cfu} / \mathrm{ml}$. Pada P1 yang diberikan 1 gr kitosan / $\mathrm{kg}$ pakan angka lempeng total bakteri sebesar 52,1 x $10^{9} \mathrm{cfu} / \mathrm{ml}$, jumlah ini lebih besar dari jumlah pada kontrol. Pada P2 dan P3 yang masing-masing diberikan 2 gr kitosan / kg pakan dan 4 gr kitosan / kg pakan angka lempeng total bakterinya adalah $25,1 \times 10^{9} \mathrm{cfu} / \mathrm{ml}$ dan $15,8 \times 10^{9}$ $\mathrm{cfu} / \mathrm{ml}$.

Tabel 2.Angka Lempeng Total Bakteri pada Saluran Pencernaan Lobster Pasir pada Media Agar Kitin

\begin{tabular}{cc}
\hline Percobaan & $\begin{array}{c}\text { Media Agar Kitin } \\
(\mathrm{cfu} / \mathrm{ml})\end{array}$ \\
\hline Kontrol & $5 \times 10^{7} \mathrm{cfu} / \mathrm{ml}$ \\
P1 & $272 \times 10^{7} \mathrm{cfu} / \mathrm{ml}$ \\
P2 & $241 \times 10^{7} \mathrm{cfu} / \mathrm{ml}$ \\
P3 & $55 \times 10^{7} \mathrm{cfu} / \mathrm{ml}$ \\
\hline
\end{tabular}

Keterangan: $\mathrm{cfu} / \mathrm{ml}=$ colony forming unit $/ \mathrm{m} 1$

Koloni-koloni yang tumbuh ini kitinolitik yang berasal baik dari tubuh lobster pasir itu sendiri dan stimulasi dari membuktikan bahwa mikroorganisme tersebut mampu mendegradasi kitin.

Mikroorganisme ini disebut bakteri kitinolitik. Koloni- koloni bakteri yang tumbuh diduga merupakan bakteri pemberian kitosan pada pakan. Dari hasil perhitungan jumlah total bakteri diperoleh hasil yaitu kontrol, P1, P2 dan P3 secara berturut-turut adalah $5 \times 10^{7}$ $\mathrm{cfu} / \mathrm{ml}, 272 \times 10^{7} \mathrm{cfu} / \mathrm{ml}, 241 \times 10^{7}$ $\mathrm{cfu} / \mathrm{ml}$ dan $55 \times 10^{7} \mathrm{cfu} / \mathrm{ml}$. 


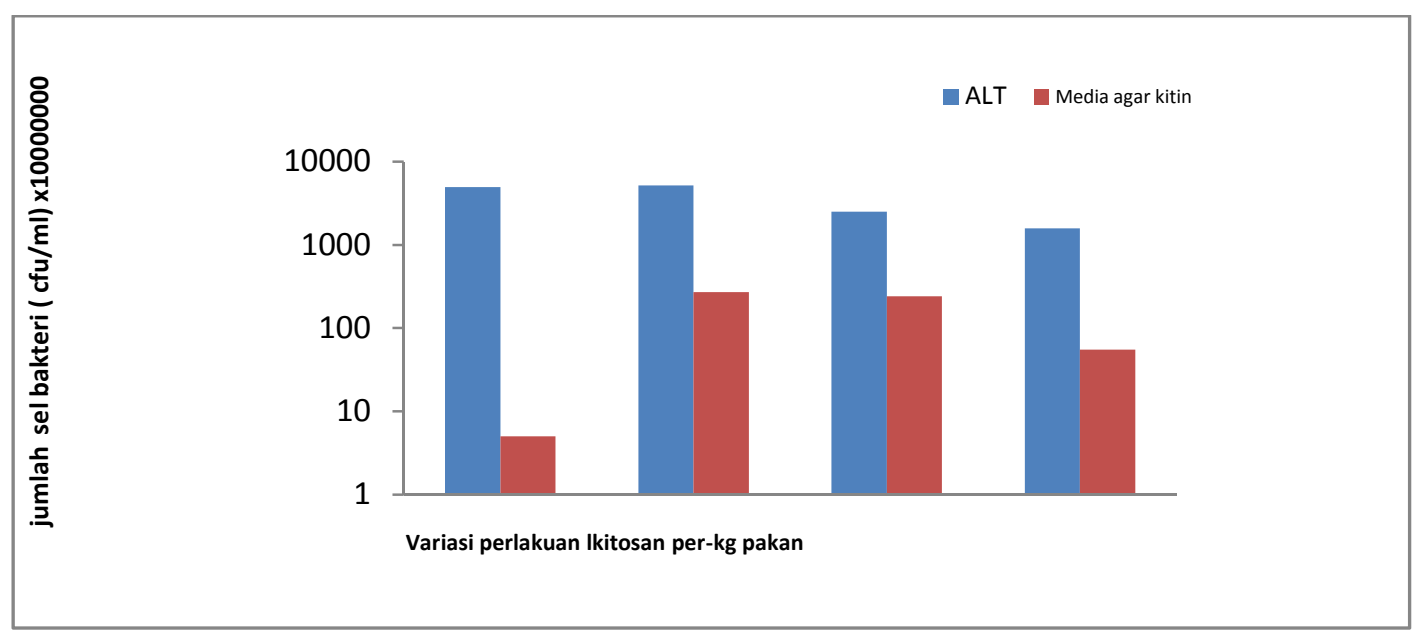

Gambar 1.Rata-rata jumlah total bakteri dan bakteri kitinolitik pada saluran pencernaan lobster pasir.

Mikroorganisme kitinolitik adalah mikroorganisme yang memiliki aktivitas kitinolitik, yaitu dapat mendegradasi kitin menggunakan enzim kitinase yang dihasilkan. Hal itu dapat dilihat pertumbuhan dan perkembangbiakan dengan mengisolasi koloni bakteri yang diduga terdapat bakteri kitinolitik ke media selektif yang mengandung kitin.

Kitinolitik merupakan proses degradasi biomassa kitin yang dilakukan oleh kerja sel mikroba. Mikroba yang dapat melakukan proses ini adalah jenis mikroba yang mampu menghasilkan kitinase, yaitu suatu jenis enzim yang mampu menghidrolisis makromolekul kitin yang terdapat di sekitar lingkungan mikroba kitinolitik tumbuh (Purkan et al, 2014).

Degradasi kitin terutama dilakukan oleh mikroorganisme, dimana kitin dapat merupakan sumber karbon dan nitrogen untuk pertumbuhannya. Terdapat dua macam lintasan perombakan kitin, lintasan perombakan kitin yang belum diketahui disebut kitinoklastik, sedangkan jika lintasan tersebut melibatkan hidrolistik ikatan $(1,4)$ glikosida, maka prosesnya disebut kitinolitik. Hidrolisis ikatan ini dilakukan oleh enzim kitinase, eksokitinase memecah bagian diasetilkitobiosa dari ujung nonreduksi suatu rantai kitin sedangkan endokitinase memecah bagian ikatan glikosida rantai kitin secara acak dan menghasilkan diasetilkitobiosa sebagai hasil utama yang bersama-sama dengan triasetilkitobiosa akan dirombak secara perlahan menjadi disakarida dan monosakarida (Setiawati et al, 2013).

Aktivitas kitinase merupakan ukuran jumlah produk yang dihasilkan dari suatu pemecahan substrat kitin. Satu unit aktivitas kitinase didefinisikan jumlah enzim yang membebaskan sebanyak $1 \mu \mathrm{mol}$ gula reduksi ( $\mathrm{N}$-asetilglukosmin) per menit ( Dewi, 2008).

Berdasarkan pengamatan koloni bakteri yang terbentuk berwarna putih susu, putih dan putih kekuningan. Jumlah bakteri yang diperoleh mengalami penurunan jumlah bakteri dengan P1 tertinggi dan P3 terendah pada media PCA dan pada media agar kitin. Angka lempeng total bakteri pada P1 dengan variasi kitosan 1 gr per-kg pakan pada media PCA sebesar 52,1 x $10^{9} \mathrm{cfu} / \mathrm{ml}$ dan pada media agar kitin sebesar $272 \mathrm{x}$ $10^{7} \mathrm{cfu} / \mathrm{ml}, \mathrm{P} 2$ dengan variasi kitosan $2 \mathrm{gr}$ per-kg pakan pada media PCA sebesar 
$25,1 \times 10^{9} \mathrm{cfu} / \mathrm{ml}$ dan pada media agar kitin media sebesar $241 \times 10^{7} \mathrm{cfu} / \mathrm{ml}$. P3 dengan variasi kitosan 4 gr per-kg pakan pada media PCA sebesar $15,8 \times 10^{9}$ cfu/ml dan pada media agar kitin sebesar $55 \times 10^{7} \mathrm{cfu} / \mathrm{ml}$, dapat dilihat dari hasil yang diperolah (Gambar 1.) membuktikan bahwa variasi kitosan yang diberikan pada pakan lobster pasir tidak mampu memicu bertambah banyaknya populasi bakteri kitinolitik pada saluran pencernaan lobster pasir berdasarkan variasi kitosan yang diberikan.

\section{SIMPULAN}

Perlakuan variasi berat kitosan per$\mathrm{kg}$ pakan tidak memberikan pengaruh berbeda nyata $(p>0.05)$ terhadap populasi bakteri kitinolitik pada salauran pencernaan lobster pasir (Panulirus homarus L.).

\section{DAFTAR PUSTAKA}

Agustina S. \& Y. Kurniasih, 2013, Pembuatan Kitosan dari Cangkang Udang dan Aplikasinya sebagai Adsorben untuk Menurunkan Kadar Logam $\mathrm{Cu}$, Seminar Nasional FMIPA UNDIKSHA III, IKIP Mataram.

Aslamsyah, S., H. Y. Azis, Sriwulan \& K. G. Wiryawan, 2009, Mikroflora Saluran Pencernaan Ikan Gurame (Osphronemus gouramy lacepede), Jurnal Ilmu Kelautan dan Perikanan 19 (1): 66-73

Damongilala, L. J., 2009, Kadar Air dan Total Bakteri pada Ikan Roa (Hemirhampus sp.) Asap dengan Metode Pencucian Bahan Baku Berbeda, Jurnal Ilmiah Sains 9 (2): 191-198.

Dewi, I. M., 2008, Isolasi Bakteri dan Uji Aktivitas Kitinase Termofilik Kasar dari Sumber Air Panas Tinggi Raja,

Simalungun Sumatra Utara, Tesis, Universitas Sumatra Utara Medan.

Fitri, L. \& Y. Yasmin, 2011, Isolasi dan Pengamatan Morfologi Koloni Bakteri Kitinolitik, Jurnal Ilmiah Pendidikan Biologi, Biologi Edukasi 3 (2): 20-25.

Mahatmanti, F. W. \& W. Sumarni, 2003, Kajian Termodinamika Penyerapan Zat Warna Indikator Metil Oranye (Mo) dalam Larutan Air oleh Adsorben Kitosan, Jurnal JSKA 6 (2): 101-111.

Mashaii, N., F. Rajabipour \& A. Shakouri, 2011, Feeding Habits of The Scalloped Spiny Lobster, Panulirus homarus (Linnaeus, 1758) (Decapoda: Palinuridae) from The South East Coast of Iran, Turkish Journal of Fisheries and Aquatic Sciences 11: 4554.

Niu, J., Y.J. Liu, H.Z. Lin, K.S. Mai, H.J. Yang, G.Y. Liang \& L.X. Tian, 2011, Effects of Dietary Chitosan on Growth, Survival and Stress Tolerance of Postlarval Shrimp, Litopenaeus vannamei, Aquaculture Nutrition 17, e406-e412.

Purkan., B. Azizah., A. Baktir \& S. Sumarsih., 2014, Eksplorasi Bakteri Kitinolitik dari Sampah Organik: Isolasi dan Karaktrisasi Enzim Kitinase, Jurnal Molekul 9 (2): 128-135.

Rostinawati, T., 2008, Skrining dan Identifikasi Bakteri Penghasil Enzim Kitinase dari Air Laut di Perairan Pantai Pondok Bali, Penelitian Mandiri, Universitas Padjadjaran Jatinangor.

Setiawati, J.E., Tarsim, Y. T. Adiputra \& S. Hudaidah, 2013, Pengaruh Penambahan Probiotik Pada Pakan dengan Dosis Berbeda Terhadap Pertumbuhan, Kelulushidupan, Efisiensi Pakan dan Retensi Protein Ikan Patin (Pangasius 
Hypophthalmus), Jurnal Rekayasa dan Teknologi Budidaya Perairan 1 (2): 2302-3600.

Trampuz, Andrej \& A. F. Widmer, 2004, Hand Hygiene: A Frequently Missed Livesaving Opportunity During Patient Care, Mayo Clinic Proceedings 79: 109-116.

Trijoko, T., Helmiati, \& Untari, 2003, Pemijahan Udang Karang (Panulirus Homarus L) Untuk Pengadaan Juvenile Bagi Konservasi Sumberdaya
Hayati, Simposium Nasional. "Perkembangan dan Inovasi Teknologi Akuakultur", Forum Temu dan Kontak Bisnis Akuakultur Indonesia, Konggres I Masyarakat Akukultur Indonesia (MAI), Semarang.

Zaki, I., 2012, Pengaruh Lama Penyimpanan terhadap Kualitas Mikrobiologi Biskuit Bayi dengan Substitusi Tepung Labu Kuning (Cucurbita moschata) dan Tepung Ikan Patin (Pangasius spp) sebagai MP-ASI, (Tesis), Universitas Diponegoro. 